\title{
Alcohol use patterns among Brazilian adults
}

\section{Padrão de uso de álcool em brasileiros adultos}

\author{
Ronaldo Laranjeira, ${ }^{1}$ llana Pinsky, ${ }^{1}$ Marcos Sanches, ${ }^{2}$ Marcos Zaleski, ${ }^{1}$ Raul Caetano ${ }^{3}$ \\ 1 Unidade de Pesquisa em Álcool e Outras Drogas (UNIAD, Alcohol and Drugs Research Unit), Department of Psychiatry, \\ Universidade Federal de São Paulo (UNIFESP), São Paulo, SP, Brazil \\ 2 Ipsos Reid, Toronto, Canada \\ 3 School of Public Health, University of Texas, Southwestern, Dallas, Texas, USA
}

\begin{abstract}
Objective: To describe patterns of alcohol consumption in the adult Brazilian population. Method: Multicluster random sample of 2,346 subjects 18 years of age or older, selected nationwide. Interviews were conducted in respondents' homes between November 2005 and April 2006. Results: About $48 \%$ of the sample had not drunk alcoholic beverages in the past year, with variations by gender, age, marital status, education, income and region of the country. Among drinkers, $29 \%$ reported drinking 5 or more drinks per occasion (men, 38\%). Sociodemographic variables are associated with the frequency and amount of drinking, alcohol problems, and alcohol abuse and dependence. Among the whole sample (including drinkers and non drinkers), 28\% reported binge drinking, $25 \%$ reported at least one kind of alcohol related problem, 3\% were alcohol abusers and another $9 \%$ were alcohol dependent. Discussion: Abstinence is high in the Brazilian population. However, elevated proportions of those who drink consume alcohol in a high risk pattern (binge-drinking), report a high level of alcohol problems, alcohol abuse and dependence. National public policies must consider these factors, as well as the regional Brazilian differences.
\end{abstract}

Descriptors: Alcoholic beverages; Population; Epidemiology; Alcohol consumption; Brazil

\section{Resumo}

Objetivo: Apresentar os padróes de consumo de bebidas alcoólicas entre a população adulta brasileira. Método: Amostra de 2.346 individuos, cuidadosamente selecionada da população brasileira com 18 anos ou mais. Amostra selecionada em todo o território brasileiro, por meio de procedimento probabilístico em múltiplos estágios. As entrevistas, realizadas nas residências, ocorreram entre novembro de 2005 e abril de 2006. Resultados: $48 \%$ da amostra relataram não haver bebido no último ano e esse indice variou de acordo com sexo, idade, estado civil, nivel educacional e de renda e regiāo do pais. Entre aqueles que bebiam, 29\% consumiam usualmente cinco ou mais doses por ocasiāo (38\% entre os homens). Fatores sociodemográficos foram relevantes em relação a todas as variáveis de consumo estudadas: frequência, quantidade, problemas, abuso e dependência. Na amostra total, incluindo os não-bebedores, $28 \%$ beberam em binge, $25 \%$ relataram ao menos um tipo de problema relacionado ao consumo, 3\% preencheram critério para abuso e $9 \%$ para dependência. Discussão: O grau de abstinência da população brasileira é alto. No entanto, os bebedores apresentam elevado nivel de consumo de risco. A prevalência de problemas relacionados ao consumo, abuso e dependência de álcool também é significativa. Políticas públicas nacionais devem levar em conta esses fatores assim como as diferenças regionais.

Descritores: Bebidas alcoólicas; População; Epidemiologia; Consumo de álcool; Brasil

\section{Introduction}

Brazil has only recently started to develop comprehensive population studies on the pattern of alcohol consumption among the adult population. Most published articles concentrate on harmful drinking (defined in different ways and identified variously as heavy consumption, harmful use, high risk consumption) and on the associated socio-economic factors. Because of the variations in sampling design and different definitions of heavy alcohol consumption, ${ }^{1}$ the results of different surveys undertaken in Brazil are not always comparable. ${ }^{2-5}$ Nonetheless, several studies demonstrate a high prevalence of harmful drinking, specially among men. One of the first studies was performed in southern city of Porto Alegre and used the instrument $\mathrm{CAGE}^{6}$ as an indicator of alcohol dependence. Rates of $9.3 \%$ for dependence and $15.5 \%$ for heavy use were found, as well as a positive association with male gender, older age, low salary and schooling, and non white ethnicity. ${ }^{5}$ Another recent study, also performed in the south of the country, has defined heavy drinking as consumption above $30 \mathrm{~g}$ of daily alcohol. In spite of the variation in the definition of heavy drinking, the rate was similar to that of the previous study: $14.3 \%$ for heavy use - with a profound distinction between men and women, $29.2 \%$ and $3.7 \%$ respectively. ${ }^{3}$

In the State of Bahia, a comprehensive study performed with 2,302 adults verified the association of high-risk consumption
Submitted: May 31, 2009

Accepted: August 27, 2009

\section{Correspondence}

Ronaldo Laranjeira

Universidade Federal de São Paulo

Rua Borges Lagoa, 564 - cj 44

04038-000 São Paulo, SP, Brasil

E-mail: laranjeira@uniad.org.br 
(defined as related to frequent states of drunkenness) with sociodemographic variables. As opposed to studies in the southern states, high-risk use showed a positive relationship with higher educational level and social class. Another interesting observation is that in a population with just less than $50 \%$ abstinence, $7 \%$ (13\% for men) showed high-risk consumption. ${ }^{7}$ A multicentre study focused on psychiatric diagnoses conducted in the cities of São Paulo, Brasília and Porto Alegre using strict criteria based on the World Health Organization's (WHO) alcohol dependence classification, has found consistent rates of nearly $8 \%$ of alcohol dependence in those major cities. $^{8}$ Other comprehensive surveys of the general population have been undertaken both in the city ${ }^{9}$ and in the state of São Paulo, ${ }^{10,11}$ including a recent study showing that both men and women had similar patterns of drinking. ${ }^{12}$

The most comprehensive studies aimed at the prevalence of psychotropic substances in Brazil were performed by the Brazilian Information Center on Psychotropic Drugs (CEBRID). Two household surveys, conducted in 2001 and 2005, investigated alcohol consumption patterns in more than one hundred cities all over the country. The prevalence of alcohol consumption in the lifetime was $68.7 \%$ and $74.6 \%$, respectively for the first and second surveys. Both surveys found $11.2 \%$ and $12.3 \%$ prevalence for alcohol dependence, also respectively for the first and the second studies. ${ }^{13,14}$

Despite the great evolution of the Brazilian literature in the last decades, even the most comprehensive studies such as those already cited, do not enable us to outline a nationwide picture of the patterns of alcohol consumption. Due to this, we still have a fragmented view of the most important data. The current study is the first with a multistage probabilistic methodology, presenting as a result a representative sample of the nationwide population. The objective of this article is to expand the knowledge regarding the use of alcohol in Brazil by describing the most prevalent drinking patterns of the Brazilian adult population, and using, for the first time, an extensive questionnaire to elicit this information.

\section{Method}

\section{Sample}

The $1^{\text {st }}$ Brazilian Nationwide Survey on Alcohol Consumption Patterns was performed by the Research Unit on Alcohol and Drugs (UNIAD) of the Universidade Federal de São Paulo (UNIFESP), from November 2005 up to April 2006. The survey covered one hundred forty-three Brazilian cities and, within them, a total of 325 census sectors, including those situated in rural areas. The interviews were carried out in the home.

The sampling design was multistage probabilistic. First the Brazilian municipalities were divided into 25 strata according to their size and region. Within each stratum a systematic selection was carried out where municipalities were pre sorted based on their income and selected with probability proportional to their size (PPS). Within each stratum, the cities were arranged by the average income and were submitted to a systematic selection, and the income composed a third stratum, which was implicit. The cities were selected in proportional probability to their estimated population (both average income and population were based on the last national socio-demographic census made by the Brazilian Institute of Geography and Statistics - IBGE). ${ }^{15}$

In the second stage of the sample, census sectors were chosen within the cities selected in the first stage. All sectors were included, even rural ones. The sectors were also chosen proportionally to their size, after having been arranged by their average income. Big cities had their sectors arranged by neighborhood and income, forming thus two implicit strata. Each allotted sector had its households counted and listed, and, after that, households were selected according to a table of random numbers. The objective was to obtain eight interviews per census sector so therefore a higher number of households were chosen anticipating the rate of non response. This rate was calculated according to the Brazilian Social Survey (PESB), per region (http:// www.uff.br/datauff/PESB.htm).

After selecting the household, the interviewer listed all the residents and the person with the nearest birthday. Only the chosen person could be interviewed, neither the person nor the household could be substituted. In order to ensure a high response rate, strict fieldwork rules were in place for cases where the interviewer was not able to find the selected person. The interviewer had to revisit the household at least 3 times at 3 different times of the day and on 3 different days of the week, including a day during the weekend.

The selected sample was composed of 2,346 interviews with adults aged 18 years or above, representing a profile of the Brazilian population, excluding native Brazilians who live in Indian reservations, and also populations who live in communities, such as prisons. Trained interviewers carried out a face-to-face interview in the selected households, with a mean duration of 53 minutes. The response rate was $66.4 \%$.

The survey's instrument was a version of the questionnaire used in the Hispanic Americans Baseline Alcohol Survey (HABLAS). ${ }^{16}$ The questionnaire was translated by the survey's coordinators and underwent a process of adaptation to the socio-cultural reality of the Brazilian population. The full Portuguese version of the questionnaire can be found on the website of the Drug and Alcohol Research Unit - UNIAD (www.uniad.org.br).

The study was approved by a human subjects/internal review board process at the university (code: CEP 1672/04). All respondents signed an informed consent form and were assured of the confidential nature of the study before the interview. They were told that this was a national pioneer study and that their participation was important to guide future government public policies.

\section{Variables}

1) Consumption of alcoholic beverages*

a) Frequency - "How often do you generally drink any alcoholic beverage" ?* The frequencies were defined as follows: Very frequent= everyday or almost everyday; Frequent: 1-4 times/week; Occasional $=1-3$ times $/$ month; Rarely = less than once $/$ month; Abstinent: less than one/year or those who have never drunk.

b) Usual quantity - "In the days you drink beer, wine, spirits with mixers or liquors, how many units do you generally drink per day"?** 
c) Binge drinking - "During the last 12 months, how much (five or more units (if male); four or more units (if female) - of any alcoholic beverage have you drunk on one single occasion"?

d) Problems related to alcohol consumption - There were 28 questions about possible problems originating from consumption, which were classified into six types: social, working, familial, legal, physical and those related to violence. Here is an example of how the question of problems associated with 'working' was formulated: "This happened to you in the last 12 months: Drinking may have affected my chances of being promoted, being given salary raise or job improvement".

e) Abuse - A positive answer to at least one of six questions on alcohol abuse of the Composite International Diagnostic Interview (CIDI). ${ }^{17}$

f) Dependence - A positive answer to at least three of seven questions on dependence of the CIDI.

g) Type of alcoholic beverage - The interviewers asked how often the interviewee consumed each of the beverages and the amount of each consumed in one single day, in the previous 12 months. The types of beverage included wine, beer, spirits with mixers and liquors. The category "beer" included beer and draft beer, "spirits with mixers" are liquors blended with fizzy drinks or industrialized juices; "distilled beverages" include cachaça, whisky, vodka, cognac and rum.

2) Socio-demographic

The variables used were: gender (male or female), age (five ranges between 18 and 24 years up to 60 years or above), schooling (four ranges from the $5^{\text {th }}$ grade of elementary school up to college or above), family income (five ranges between up to $\mathrm{R} \$ 450.00$ and more than $\mathrm{R} \$ 2,500.00$, as well as those who did not know or refused to answer - $1 \mathrm{R} \$$, the Brazilian currency Real, is worth approximately 0.5 US Dollars), marital status (distributed among single, married/ concubines, widowers, separated/divorced), Brazilian geographic regions (Northern, Center-Western, Northeastern, Southeastern, Southern), area (countryside or capital/metropolitan region), rural (rural sector or urban sector).

\section{Statistical analysis}

The data were weighted to take into account the probability of the sample selection and non response rates. The post-stratification weights were calculated to adjust the sample to the known distributions of the population regarding certain demographic variables (gender, age and region of the country). For the statistical analyses to take into account the sampling design, all analyses were performed with the module "Complex Samples" of the SPSS (Statistical Program for Social Science. Version 13.0).

The statistical test used for contingency tables was the chisquare test. Means were compared using the T-student test for independent samples or ANOVA with Bonferroni correction when more than two means were compared, The significance level adopted was $5 \%$.

\section{Results}

\section{Characteristics of the sample}

More than half of the interviewees were women (52.4\%), who had, at most, finished elementary school (43.8\%) - only $11 \%$ of the total had finished college (Table 1 ). The majority of the sample were married (61.2\%) and $26.4 \%$ of the total were single. Regarding the family income, $87.6 \%$ reported income of up to R\$ 2,500.00 and more than one third of the total population earned up to $R \$ 450.00$. The majority of the interviewees lived in the Southeastern (45\%) and Northeastern (26\%) regions of Brazil. However, it should be pointed that the sample also represented the Northern (8\%) and Center-Western (6\%) regions, which are often excluded from surveys due to their relatively small population and difficulty of access.

\section{Drinking frequency}

One quarter of the Brazilian adult population consumes alcohol very frequently (6\%) or frequently (19\%) and almost half of the population is abstinent (Table 2). These data vary according to the socio-demographic and regional data. Therefore, abstinence is clearly lower among men, inhabitants of the Southern region, singles, and those with higher schooling and income. Lower age is also related to lower abstinence and higher alcohol consumption frequency. However, this same relationship was not found in the highest range of drinking frequency $-7 \%$ of adults aged 60 years or more report very frequent drinking. There were no significant differences in this consumption variable per area or sector.

\section{Usual quantity}

Among drinkers, 29\% report that the usual quantity consumed is five units or more (Table 3). We observed that results vary according to the respondents' socio-demographic characteristics. In relation to gender, for example, while $38 \%$ of men report a habitual consumption of five units or more per occasion, among women, the rate is $17 \%$. Again, higher alcohol consumption is found among singles and the lowest age ranges (up to 44 years of age). Contrary to the information about frequency, the highest quantities of alcohol consumed are in the Northeastern and Center-Western regions and the lowest are in the Southern region. Finally, there is a significant difference between the areas in the usual quantity of alcohol consumed, with higher usual quantities (in the highest range) being reported by inhabitants of capitals and metropolitan regions.

* Including beer, wine, liquors (rum, cachaça, whisky, vodka, etc), spirits with mixers (liquors blended with juices or fizzy drinks with low alcohol grade).

** The measure unit employed in the study and in the assessment was the dose. It corresponds, in average, to a beer can or a draft beer of $350 \mathrm{ml}$; a glass of wine of $90 \mathrm{ml}$; one dose of liquor of $30 \mathrm{ml}$; one can or a small bottle of any "ice" beverage. Each dose contains nearly 10-12 grams of alcohol. ${ }^{23}$ 
Table 1 - Socio-demographic variables of the sample, divided per gender (\%)

\begin{tabular}{|c|c|c|c|c|c|c|c|c|c|c|}
\hline & \multirow[t]{2}{*}{ Demographic } & \multicolumn{3}{|c|}{ Male } & \multicolumn{3}{|c|}{ Female } & \multicolumn{3}{|c|}{ Total } \\
\hline & & (\%) & (n) & (SD) & $(\%)$ & (n) & (SD) & $(\%)$ & (n) & (SD) \\
\hline \multirow[t]{5}{*}{ Age } & $18-24$ years & $21 \%$ & 159 & $1.5 \%$ & $19 \%$ & 209 & $1.3 \%$ & $20 \%$ & 368 & $1.0 \%$ \\
\hline & $25-34$ years & $24 \%$ & 238 & $1.5 \%$ & $23 \%$ & 350 & $1.2 \%$ & $23 \%$ & 588 & $0.9 \%$ \\
\hline & $35-44$ years & $21 \%$ & 192 & $1.5 \%$ & $21 \%$ & 296 & $1.1 \%$ & $21 \%$ & 488 & $0.9 \%$ \\
\hline & $45-59$ years & $21 \%$ & 200 & $1.5 \%$ & $22 \%$ & 301 & $1.1 \%$ & $21 \%$ & 501 & $1.0 \%$ \\
\hline & 60 years or above & $13 \%$ & 161 & $1.2 \%$ & $15 \%$ & 240 & $1.1 \%$ & $14 \%$ & 401 & $0.9 \%$ \\
\hline \multirow[t]{4}{*}{ Marital status } & Single & $28 \%$ & 228 & $1.8 \%$ & $25 \%$ & 299 & $1.4 \%$ & $26 \%$ & 527 & $1.1 \%$ \\
\hline & Married/Concubine & $65 \%$ & 628 & $1.8 \%$ & $58 \%$ & 785 & $1.6 \%$ & $61 \%$ & 1413 & $1.2 \%$ \\
\hline & Widower & $2 \%$ & 29 & $0.4 \%$ & $10 \%$ & 171 & $0.9 \%$ & $6 \%$ & 200 & $0.5 \%$ \\
\hline & Divorced/Separated & $4 \%$ & 65 & $0.6 \%$ & $8 \%$ & 141 & $0.8 \%$ & $6 \%$ & 206 & $0.5 \%$ \\
\hline \multirow[t]{4}{*}{ Schooling } & $\begin{array}{l}\text { Up to the } 5^{\text {th }} \text { grade, elementary } \\
\text { school }\end{array}$ & $37 \%$ & 399 & $1.7 \%$ & $36 \%$ & 564 & $1.6 \%$ & $37 \%$ & 963 & $1.3 \%$ \\
\hline & $6^{\text {th }}-9^{\text {th }}$ grade, elementary school & $25 \%$ & 219 & $1.8 \%$ & $24 \%$ & 317 & $1.4 \%$ & $24 \%$ & 536 & $1.2 \%$ \\
\hline & High school & $28 \%$ & 271 & $1.6 \%$ & $29 \%$ & 409 & $1.5 \%$ & $28 \%$ & 680 & $1.1 \%$ \\
\hline & College & $10 \%$ & 61 & $1.6 \%$ & $11 \%$ & 106 & $1.3 \%$ & $11 \%$ & 167 & $1.1 \%$ \\
\hline \multirow[t]{6}{*}{ Family income } & Up to $R \$ 450.00$ & $32 \%$ & 362 & $1.9 \%$ & $38 \%$ & 613 & $1.8 \%$ & $35 \%$ & 975 & $1.5 \%$ \\
\hline & $\mathrm{R} \$ 451.00$ to $\mathrm{R} \$ 750.00$ & $19 \%$ & 194 & $1.5 \%$ & $20 \%$ & 273 & $1.2 \%$ & $20 \%$ & 467 & $1.0 \%$ \\
\hline & $\mathrm{R} \$ 751.00$ to $\mathrm{R} \$ 1200.00$ & $22 \%$ & 187 & $1.4 \%$ & $16 \%$ & 206 & $1.3 \%$ & $19 \%$ & 393 & $1.1 \%$ \\
\hline & $\mathrm{R} \$ 1201.00$ to $\mathrm{R} \$ 2500.00$ & $16 \%$ & 119 & $1.5 \%$ & $12 \%$ & 139 & $1.3 \%$ & $14 \%$ & 258 & $1.0 \%$ \\
\hline & More than $\mathrm{R} \$ 2500.00$ & $7 \%$ & 48 & $1.1 \%$ & $5 \%$ & 52 & $1.0 \%$ & $6 \%$ & 100 & $0.8 \%$ \\
\hline & Does not know/Refuses to answer & $4 \%$ & 40 & $0.8 \%$ & $8 \%$ & 113 & $1.0 \%$ & $6 \%$ & 153 & $0.7 \%$ \\
\hline \multirow[t]{5}{*}{ Region } & Northern & $8 \%$ & 64 & $1.5 \%$ & $7 \%$ & 83 & $0.8 \%$ & $8 \%$ & 147 & $0.8 \%$ \\
\hline & Center-Western & $6 \%$ & 75 & $0.7 \%$ & $7 \%$ & 116 & $0.7 \%$ & $6 \%$ & 191 & $0.4 \%$ \\
\hline & Northeastern & $26 \%$ & 276 & $1.7 \%$ & $26 \%$ & 406 & $1.3 \%$ & $26 \%$ & 682 & $1.0 \%$ \\
\hline & Southeastern & $44 \%$ & 407 & $2.0 \%$ & $45 \%$ & 598 & $1.5 \%$ & $45 \%$ & 1005 & $1.2 \%$ \\
\hline & Southern & $15 \%$ & 128 & $1.4 \%$ & $15 \%$ & 193 & $1.2 \%$ & $15 \%$ & 321 & $0.8 \%$ \\
\hline \multirow[t]{2}{*}{ Area } & Countryside & $65 \%$ & 619 & $3.1 \%$ & $62 \%$ & 889 & $2.7 \%$ & $63 \%$ & 1508 & $2.6 \%$ \\
\hline & Capital/Metropolitan region & $35 \%$ & 331 & $3.1 \%$ & $38 \%$ & 507 & $2.7 \%$ & $37 \%$ & 838 & $2.6 \%$ \\
\hline \multirow[t]{2}{*}{ Rural } & Urban & $86 \%$ & 799 & $1.8 \%$ & $84 \%$ & 1181 & $2.0 \%$ & $85 \%$ & 1980 & $1.8 \%$ \\
\hline & Rural & $14 \%$ & 151 & $1.8 \%$ & $16 \%$ & 215 & $2.0 \%$ & $15 \%$ & 366 & $1.8 \%$ \\
\hline
\end{tabular}

\section{Binge drinking}

Table 3 shows the data of binge consumption, which is an internationally recognized term for the acute consumption of five or more units for men and four or more units for women in one single occasion. Of the total sample (including those who are abstinent), $28 \%$ reported at least one occasion of binge drinking in the 12 months prior to the interview. These numbers varied between men (40\%) and women (18\%) and between young adults (40\%) and the population aged above 45 years (20 to 10\%). A higher frequency of binge drinking was also found among singles and those with higher income. As to schooling, there was a trend of higher rates of binge drinking in the sample with schooling above the $5^{\text {th }}$ grade of elementary school. However, there is a slight reversal of this trend arriving at college level. There were no regional variations in this consumption pattern, neither in relation to area nor sector.

\section{Alcohol problems}

One quarter of the sample studied (including non drinkers) reports at least one problem related to alcohol consumption (Table 4). There were important socio-demographic variations.
The highest rates of problem drinking were found among men, youngsters, singles and the population living in metropolitan regions and other urban areas. Those problems were also more prevalent in families with a higher income and those who are studying (especially in middle and high school students). There were no significant differences between Brazilian regions. As mentioned in the methodology, the problems were divided into six types, non exclusive (that is, the interviewees could mention problems related to more than one type). The highest frequency of problems cited referred to physical problems $(22 \%$ of the interviewees). Next were familial (11\%), social (10\%), violence (10\%) and working (5\%) problems. Of note, legal problems were cited by only $1 \%$ of the sample.

\section{Abuse and dependence}

Among the Brazilian adult population, 3\% show alcohol abuse and $9 \%$ is alcohol dependent. Table 4 shows the prevalence of abuse and/or dependence in the Brazilian population according to several demographic characteristics. These conditions are associated with gender - of every five men, at least one has one of these conditions, whereas of every twenty women one abuses or 
Table 2 - Frequency of consumption of alcoholic beverages in the prior twelve months and its relationship with socio-demographic variables (\%)

\begin{tabular}{|c|c|c|c|c|c|c|c|c|c|c|c|c|}
\hline \multirow[t]{2}{*}{ Demographic } & & \multicolumn{2}{|c|}{ Very frequent } & \multicolumn{2}{|c|}{ Frequent } & \multicolumn{2}{|c|}{ Occasional } & \multicolumn{2}{|c|}{ Rarely } & \multicolumn{2}{|c|}{ Abstinent } & \multirow[t]{2}{*}{ p-value } \\
\hline & & $(\%)$ & (SD) & $(\%)$ & (SD) & $(\%)$ & (SD) & $(\%)$ & (SD) & $(\%)$ & (SD) & \\
\hline \multirow[t]{2}{*}{ Gender } & Male & $11 \%$ & $1.2 \%$ & $28 \%$ & $2.0 \%$ & $19 \%$ & $1.5 \%$ & $8 \%$ & $1.0 \%$ & $35 \%$ & $1.9 \%$ & $<0.001$ \\
\hline & Female & $2 \%$ & $0.4 \%$ & $11 \%$ & $1.0 \%$ & $16 \%$ & $1.3 \%$ & $12 \%$ & $1.1 \%$ & $59 \%$ & $1.7 \%$ & \\
\hline \multirow[t]{5}{*}{ Age } & 18 - 24 years & $4 \%$ & $1.2 \%$ & $22 \%$ & $2.5 \%$ & $24 \%$ & $2.6 \%$ & $13 \%$ & $2.1 \%$ & $38 \%$ & $3.2 \%$ & $<0.001$ \\
\hline & $25-34$ years & $4 \%$ & $0.7 \%$ & $24 \%$ & $2.0 \%$ & $19 \%$ & $1.9 \%$ & $11 \%$ & $1.5 \%$ & $42 \%$ & $2.3 \%$ & \\
\hline & $35-44$ years & $7 \%$ & $1.7 \%$ & $23 \%$ & $2.5 \%$ & $18 \%$ & $2.3 \%$ & $8 \%$ & $1.3 \%$ & $44 \%$ & $2.9 \%$ & \\
\hline & $45-59$ years & $8 \%$ & $1.3 \%$ & $16 \%$ & $2.1 \%$ & $14 \%$ & $1.9 \%$ & $9 \%$ & $1.6 \%$ & $54 \%$ & $2.8 \%$ & \\
\hline & 60 years or above & $7 \%$ & $1.6 \%$ & $8 \%$ & $1.7 \%$ & $10 \%$ & $2.0 \%$ & $8 \%$ & $1.7 \%$ & $68 \%$ & $2.9 \%$ & \\
\hline \multirow{5}{*}{$\begin{array}{l}\text { Marital } \\
\text { status }\end{array}$} & & & & & & & & & & & & $<0.001$ \\
\hline & Single & $5 \%$ & $1.0 \%$ & $23 \%$ & $2.3 \%$ & $20 \%$ & $2.2 \%$ & $13 \%$ & $1.8 \%$ & $39 \%$ & $2.7 \%$ & \\
\hline & Married/Concubine & $7 \%$ & $0.9 \%$ & $19 \%$ & $1.4 \%$ & $16 \%$ & $1.2 \%$ & $9 \%$ & $0.9 \%$ & $49 \%$ & $1.7 \%$ & \\
\hline & Widower & $2 \%$ & $1.1 \%$ & $6 \%$ & $2.5 \%$ & $11 \%$ & $2.8 \%$ & $10 \%$ & $2.8 \%$ & $72 \%$ & $4.5 \%$ & \\
\hline & Divorced/Separated & $7 \%$ & $2.5 \%$ & $19 \%$ & $2.9 \%$ & $17 \%$ & $3.4 \%$ & $11 \%$ & $2.9 \%$ & $45 \%$ & $4.2 \%$ & \\
\hline \multirow[t]{5}{*}{ Schooling } & $\begin{array}{l}\text { Up to the } 5^{\text {th }} \text { grade, } \\
\text { elementary school }\end{array}$ & $6 \%$ & $0.9 \%$ & $12 \%$ & $1.3 \%$ & $12 \%$ & $1.3 \%$ & $8 \%$ & $1.2 \%$ & $62 \%$ & $2.1 \%$ & $<0.001$ \\
\hline & $6^{\text {th }}-9^{\text {th }}$ grade, elementary & & & & & & & & & & & \\
\hline & school & $6 \%$ & $1.1 \%$ & $25 \%$ & $2.2 \%$ & $17 \%$ & $1.7 \%$ & $10 \%$ & $1.4 \%$ & $42 \%$ & $2.5 \%$ & \\
\hline & High school & $5 \%$ & $0.9 \%$ & $23 \%$ & $1.8 \%$ & $20 \%$ & $1.8 \%$ & $12 \%$ & $1.5 \%$ & $40 \%$ & $2.2 \%$ & \\
\hline & College & $7 \%$ & $2.4 \%$ & $20 \%$ & $3.9 \%$ & $27 \%$ & $4.5 \%$ & $12 \%$ & $2.8 \%$ & $34 \%$ & $4.2 \%$ & \\
\hline \multirow{7}{*}{$\begin{array}{l}\text { Family } \\
\text { income }\end{array}$} & & & & & & & & & & & & $<0.001$ \\
\hline & Up to $R \$ 450.00$ & $6 \%$ & $1.0 \%$ & $14 \%$ & $1.3 \%$ & $13 \%$ & $1.5 \%$ & $10 \%$ & $1.2 \%$ & $57 \%$ & $2.1 \%$ & \\
\hline & $\mathrm{R} \$ 451.00$ to $\mathrm{R} \$ 750.00$ & $4 \%$ & $1.1 \%$ & $20 \%$ & $2.3 \%$ & $17 \%$ & $2.2 \%$ & $11 \%$ & $1.8 \%$ & $48 \%$ & $2.6 \%$ & \\
\hline & $\mathrm{R} \$ 751.00$ to $\mathrm{R} \$ 1200.00$ & $6 \%$ & $1.3 \%$ & $21 \%$ & $2.5 \%$ & $21 \%$ & $2.4 \%$ & $11 \%$ & $1.9 \%$ & $41 \%$ & $3.2 \%$ & \\
\hline & $\mathrm{R} \$ 1201.00$ to $\mathrm{R} \$ 2500.00$ & $11 \%$ & $2.3 \%$ & $25 \%$ & $3.5 \%$ & $24 \%$ & $3.1 \%$ & $7 \%$ & $2.0 \%$ & $33 \%$ & $3.4 \%$ & \\
\hline & More than $\mathrm{R} \$ 2500.00$ & $7 \%$ & $2.5 \%$ & $27 \%$ & $5.5 \%$ & $22 \%$ & $4.7 \%$ & $12 \%$ & $3.8 \%$ & $32 \%$ & $5.3 \%$ & \\
\hline & $\begin{array}{l}\text { Does not know/refuses to } \\
\text { answer }\end{array}$ & $4 \%$ & $1.8 \%$ & $16 \%$ & $4.2 \%$ & $12 \%$ & $2.7 \%$ & $6 \%$ & $2.0 \%$ & $62 \%$ & $5.0 \%$ & \\
\hline \multirow[t]{5}{*}{ Region } & Northern & $4 \%$ & $1.9 \%$ & $10 \%$ & $3.3 \%$ & $21 \%$ & $3.9 \%$ & $11 \%$ & $1.8 \%$ & $54 \%$ & $5.4 \%$ & 0.017 \\
\hline & Center-Western & $6 \%$ & $2.0 \%$ & $18 \%$ & $5.4 \%$ & $18 \%$ & $5.3 \%$ & $11 \%$ & $3.1 \%$ & $47 \%$ & $2.4 \%$ & \\
\hline & Northeastern & $3 \%$ & $1.1 \%$ & $21 \%$ & $2.1 \%$ & $16 \%$ & $1.6 \%$ & $10 \%$ & $1.4 \%$ & $50 \%$ & $2.5 \%$ & \\
\hline & Southeastern & $6 \%$ & $0.8 \%$ & $18 \%$ & $1.6 \%$ & $17 \%$ & $1.5 \%$ & $10 \%$ & $1.4 \%$ & $50 \%$ & $2.0 \%$ & \\
\hline & Southern & $11 \%$ & $2.2 \%$ & $25 \%$ & $3.8 \%$ & $19 \%$ & $3.0 \%$ & $10 \%$ & $2.1 \%$ & $35 \%$ & $4.5 \%$ & \\
\hline \multirow[t]{2}{*}{ Area } & Countryside & $6 \%$ & $0.8 \%$ & $18 \%$ & $1.4 \%$ & $17 \%$ & $1.2 \%$ & $11 \%$ & $1.1 \%$ & $49 \%$ & $1.7 \%$ & 0.455 \\
\hline & $\begin{array}{l}\text { Capital/Metropolitan } \\
\text { region }\end{array}$ & $6 \%$ & $1.0 \%$ & $21 \%$ & $2.1 \%$ & $18 \%$ & $1.8 \%$ & $8 \%$ & $1.1 \%$ & $47 \%$ & $2.3 \%$ & \\
\hline \multirow[t]{2}{*}{ Rural } & Urban & $6 \%$ & $0.7 \%$ & $20 \%$ & $1.3 \%$ & $17 \%$ & $1.1 \%$ & $10 \%$ & $0.9 \%$ & $47 \%$ & $1.4 \%$ & 0.079 \\
\hline & Rural & $7 \%$ & $1.7 \%$ & $13 \%$ & $2.0 \%$ & $17 \%$ & $2.3 \%$ & $11 \%$ & $2.0 \%$ & $54 \%$ & $3.6 \%$ & \\
\hline
\end{tabular}

is dependent. Alcohol abuse and dependence are more prevalent in the first two age ranges and among singles and both conditions tend to decrease with age. The population with college level education tends to a lower prevalence of alcohol dependence. Dependence seems to be associated with lower income levels, and, particularly in our study, the range between $\mathrm{R} \$ 1200$ and $\mathrm{R} \$ 2500$ presented quite a high prevalence of dependence. There were no regional variations, regarding either the area or urban versus rural sector.

\section{The most consumed beverages}

Of the annual number of units consumed by Brazilian adults of both genders, of any age and region of the country, beer and draft beer make up nearly $60 \%$. Beer and wine are the most consumed beverages by the Brazilian population, and there are no variations in their percentage of consumption, except in few cases (Table 5). There is a significant difference in the concentration of beer consumption per age range (people older than 60 years concentrate their consumption less on beer and more on other beverages) and per educational level (lower consumption of beer in higher school levels). Regarding wine, its consumption is higher among women and inhabitants of urban settings, and lower in the Northeastern region.

On the other hand, Table 5 shows important socio-demographic differences regarding the distribution of units consumed of distilled and spirits with mixers. Liquors are consumed in a higher proportion by men, with lower schooling, inhabitants 
Table 3 - Usual quantity consumed and binge drinking and their relationship with the socio-demographic variables

\begin{tabular}{|c|c|c|c|c|c|c|c|c|c|c|c|c|c|c|}
\hline \multirow{3}{*}{ Demographic } & & \multicolumn{8}{|c|}{ Usual quantity } & \multirow{3}{*}{$p$-value } & \multicolumn{4}{|c|}{ Binge drinking } \\
\hline & & \multicolumn{2}{|c|}{$\begin{array}{c}12 \text { or more } \\
\text { units }\end{array}$} & \multicolumn{2}{|c|}{$\begin{array}{c}\text { From } 5 \text { to } 11 \\
\text { units }\end{array}$} & \multicolumn{2}{|c|}{$\begin{array}{c}\text { From } 3 \text { to } 4 \\
\text { units }\end{array}$} & \multicolumn{2}{|c|}{ Up to 2 units } & & \multirow{2}{*}{$\begin{array}{l}\text { No } \\
(\%) \\
\end{array}$} & \multirow{2}{*}{$\begin{array}{c}\text { Yes } \\
(\%) \\
\end{array}$} & \multirow[b]{2}{*}{ (SD) } & \multirow[t]{2}{*}{$\overline{p \text {-value }}$} \\
\hline & & $(\%)$ & (SD) & $(\%)$ & (SD) & $(\%)$ & (SD) & $(\%)$ & (SD) & & & & & \\
\hline \multirow[t]{2}{*}{ Gender } & Male & $11 \%$ & $2.3 \%$ & $27 \%$ & $2.3 \%$ & $25 \%$ & $2.0 \%$ & $38 \%$ & $2.7 \%$ & $<0.001$ & $60 \%$ & $40 \%$ & $2.1 \%$ & $<0.001$ \\
\hline & Female & $3 \%$ & $0.9 \%$ & $14 \%$ & $1.9 \%$ & $19 \%$ & $2.0 \%$ & $63 \%$ & $2.7 \%$ & & $82 \%$ & $18 \%$ & $1.3 \%$ & \\
\hline \multirow[t]{5}{*}{ Age } & $\begin{array}{l}18-24 \\
\text { years }\end{array}$ & $9 \%$ & $2.8 \%$ & $24 \%$ & $3.4 \%$ & $30 \%$ & $3.5 \%$ & $37 \%$ & $4.2 \%$ & $<0.001$ & $60 \%$ & $40 \%$ & $3.0 \%$ & $<0.001$ \\
\hline & $\begin{array}{l}25-34 \\
\text { years }\end{array}$ & $9 \%$ & $1.9 \%$ & $26 \%$ & $2.9 \%$ & $20 \%$ & $2.6 \%$ & $45 \%$ & $3.2 \%$ & & $63 \%$ & $37 \%$ & $2.3 \%$ & \\
\hline & $\begin{array}{l}35-44 \\
\text { years }\end{array}$ & $8 \%$ & $2.2 \%$ & $24 \%$ & $3.4 \%$ & $20 \%$ & $3.0 \%$ & $48 \%$ & $3.8 \%$ & & $72 \%$ & $28 \%$ & $2.6 \%$ & \\
\hline & $\begin{array}{l}45-59 \\
\text { years }\end{array}$ & $4 \%$ & $1.4 \%$ & $15 \%$ & $2.5 \%$ & $24 \%$ & $3.2 \%$ & $57 \%$ & $3.6 \%$ & & $80 \%$ & $20 \%$ & $2.2 \%$ & \\
\hline & $\begin{array}{l}60 \text { years or } \\
\text { above }\end{array}$ & $5 \%$ & $2.4 \%$ & $12 \%$ & $3.7 \%$ & $12 \%$ & $3.6 \%$ & $70 \%$ & $4.9 \%$ & & $90 \%$ & $10 \%$ & $2.0 \%$ & \\
\hline \multirow{5}{*}{$\begin{array}{l}\text { Marital } \\
\text { status }\end{array}$} & Single & $10 \%$ & $2.6 \%$ & $25 \%$ & $3.2 \%$ & $27 \%$ & $3.5 \%$ & $38 \%$ & $3.6 \%$ & 0.027 & $60 \%$ & $40 \%$ & $2.6 \%$ & $<0.001$ \\
\hline & $\begin{array}{l}\text { Married/ } \\
\text { Concubine }\end{array}$ & $7 \%$ & $1.3 \%$ & $21 \%$ & $1.8 \%$ & $20 \%$ & $1.7 \%$ & $53 \%$ & $2.5 \%$ & & $75 \%$ & $25 \%$ & $1.5 \%$ & \\
\hline & Widower & $1 \%$ & $1.5 \%$ & $15 \%$ & $7.8 \%$ & $25 \%$ & $7.9 \%$ & $58 \%$ & $9.4 \%$ & & $87 \%$ & $13 \%$ & $3.3 \%$ & \\
\hline & Divorced/ & $9 \%$ & $4.0 \%$ & $22 \%$ & $5.1 \%$ & $19 \%$ & $4.4 \%$ & $50 \%$ & $6.7 \%$ & & $75 \%$ & $25 \%$ & $3.9 \%$ & \\
\hline & Separated & & & & & & & & & & & & & \\
\hline \multirow[t]{4}{*}{ Schooling } & $\begin{array}{l}\text { Up to the } 5^{\text {th }} \\
\text { grade, } \\
\text { elementary } \\
\text { school }\end{array}$ & $7 \%$ & $2.0 \%$ & $20 \%$ & $3.0 \%$ & $22 \%$ & $2.6 \%$ & $51 \%$ & $3.8 \%$ & 0.164 & $81 \%$ & $19 \%$ & $1.9 \%$ & $<0.001$ \\
\hline & $\begin{array}{l}6^{\text {th }}-9^{\text {th }} \text { grade, } \\
\text { elementary } \\
\text { school }\end{array}$ & $9 \%$ & $2.0 \%$ & $24 \%$ & $2.6 \%$ & $22 \%$ & $2.8 \%$ & $45 \%$ & $3.2 \%$ & & $67 \%$ & $33 \%$ & $2.3 \%$ & \\
\hline & High school & $7 \%$ & $1.8 \%$ & $25 \%$ & $2.7 \%$ & $25 \%$ & $2.6 \%$ & $43 \%$ & $3.3 \%$ & & $64 \%$ & $36 \%$ & $2.4 \%$ & \\
\hline & College & $5 \%$ & $3.3 \%$ & $14 \%$ & $4.1 \%$ & $19 \%$ & $4.4 \%$ & $63 \%$ & $5.1 \%$ & & $72 \%$ & $28 \%$ & $4.5 \%$ & \\
\hline \multirow[t]{6}{*}{$\begin{array}{l}\text { Family } \\
\text { income }\end{array}$} & $\begin{array}{l}\text { Up to } \\
\mathrm{R} \$ 450.00\end{array}$ & $8 \%$ & $1.8 \%$ & $23 \%$ & $3.1 \%$ & $25 \%$ & $2.4 \%$ & $44 \%$ & $3.4 \%$ & 0.824 & $75 \%$ & $25 \%$ & $1.9 \%$ & $<0.001$ \\
\hline & $\begin{array}{l}\mathrm{R} \$ 451.00 \text { to } \\
\mathrm{R} \$ 750.00\end{array}$ & $9 \%$ & $2.6 \%$ & $20 \%$ & $3.1 \%$ & $22 \%$ & $3.2 \%$ & $49 \%$ & $4.0 \%$ & & $73 \%$ & $27 \%$ & $2.4 \%$ & \\
\hline & $\begin{array}{l}\mathrm{R} \$ 751.00 \text { to } \\
\mathrm{R} \$ 1200.00\end{array}$ & $6 \%$ & $2.1 \%$ & $25 \%$ & $3.4 \%$ & $21 \%$ & $3.3 \%$ & $48 \%$ & $4.5 \%$ & & $70 \%$ & $30 \%$ & $2.6 \%$ & \\
\hline & $\begin{array}{l}\mathrm{R} \$ 1201.00 \text { to } \\
\mathrm{R} \$ 2500.00\end{array}$ & $9 \%$ & $3.6 \%$ & $19 \%$ & $3.7 \%$ & $21 \%$ & $3.8 \%$ & $51 \%$ & $4.7 \%$ & & $61 \%$ & $39 \%$ & $3.9 \%$ & \\
\hline & $\begin{array}{l}\text { More than } \\
R \$ 2500.00\end{array}$ & $3 \%$ & $2.7 \%$ & $24 \%$ & $5.9 \%$ & $19 \%$ & $5.0 \%$ & $54 \%$ & $6.5 \%$ & & $63 \%$ & $37 \%$ & $5.3 \%$ & \\
\hline & $\begin{array}{l}\text { Does not } \\
\text { know } \\
\text { /refuses to } \\
\text { answer }\end{array}$ & $4 \%$ & $2.7 \%$ & $16 \%$ & $5.7 \%$ & $24 \%$ & $6.4 \%$ & $56 \%$ & $8.1 \%$ & & $84 \%$ & $16 \%$ & $3.1 \%$ & \\
\hline \multirow[t]{5}{*}{ Region } & Northern & $9 \%$ & $3.0 \%$ & $24 \%$ & $8.7 \%$ & $21 \%$ & $5.3 \%$ & $45 \%$ & $10.6 \%$ & 0.003 & $79 \%$ & $21 \%$ & $5.6 \%$ & 0.106 \\
\hline & $\begin{array}{l}\text { Center- } \\
\text { Western }\end{array}$ & $7 \%$ & $3.5 \%$ & $31 \%$ & $6.5 \%$ & $25 \%$ & $3.0 \%$ & $37 \%$ & $5.8 \%$ & & $73 \%$ & $27 \%$ & $4.9 \%$ & \\
\hline & Northeastern & $13 \%$ & $4.7 \%$ & $25 \%$ & $3.9 \%$ & $25 \%$ & $3.2 \%$ & $36 \%$ & $4.2 \%$ & & $70 \%$ & $30 \%$ & $2.7 \%$ & \\
\hline & Southeastern & $6 \%$ & $1.4 \%$ & $20 \%$ & $2.1 \%$ & $25 \%$ & $2.2 \%$ & $50 \%$ & $2.9 \%$ & & $74 \%$ & $26 \%$ & $1.8 \%$ & \\
\hline & Southern & $4 \%$ & $1.9 \%$ & $18 \%$ & $3.7 \%$ & $12 \%$ & $2.3 \%$ & $66 \%$ & $5.4 \%$ & & $64 \%$ & $36 \%$ & $3.9 \%$ & \\
\hline \multirow[t]{3}{*}{ Area } & Countryside & $4 \%$ & $1.0 \%$ & $22 \%$ & $2.2 \%$ & $22 \%$ & $1.7 \%$ & $51 \%$ & $2.8 \%$ & 0.007 & $73 \%$ & $27 \%$ & $1.7 \%$ & 0.083 \\
\hline & Capital/ & $12 \%$ & $3.2 \%$ & $21 \%$ & $2.5 \%$ & $22 \%$ & $2.3 \%$ & $44 \%$ & $3.6 \%$ & & $69 \%$ & $31 \%$ & $2.2 \%$ & \\
\hline & $\begin{array}{l}\text { Metropolitan } \\
\text { region }\end{array}$ & & & & & & & & & & & & & \\
\hline \multirow[t]{2}{*}{ Rural } & Urban & $8 \%$ & $1.6 \%$ & $21 \%$ & $1.7 \%$ & $22 \%$ & $1.4 \%$ & $48 \%$ & $2.3 \%$ & 0.281 & $71 \%$ & $29 \%$ & $1.4 \%$ & 0.287 \\
\hline & Rural & $3 \%$ & $1.5 \%$ & $26 \%$ & $5.2 \%$ & $23 \%$ & $3.7 \%$ & $49 \%$ & $5.5 \%$ & & $75 \%$ & $25 \%$ & $3.2 \%$ & \\
\hline
\end{tabular}


Table 4 - Related problems, alcohol abuse and dependence and their relationship with the socio-demographic variables (\%)

\begin{tabular}{|c|c|c|c|c|c|c|c|}
\hline \multirow[t]{2}{*}{ Demographic } & & \multicolumn{3}{|c|}{ At least one problem } & \multicolumn{3}{|c|}{ Abuse or dependence } \\
\hline & & $(\%)$ & (SD) & p-value* & $(\%)$ & (SD) & $p$-value* \\
\hline \multirow[t]{2}{*}{ Gender } & Male & $40 \%$ & $1.8 \%$ & $<0.001$ & $19 \%$ & $1.8 \%$ & $<0.001$ \\
\hline & Female & $11 \%$ & $1.0 \%$ & & $4 \%$ & $0.7 \%$ & \\
\hline \multirow[t]{5}{*}{ Age } & $18-24$ years & $34 \%$ & $3.2 \%$ & $\begin{array}{c}<0.001 \text { (ad; ae; be; } \\
\text { ce) }\end{array}$ & $19 \%$ & $2.9 \%$ & $\begin{array}{c}<0.001 \text { (ac; ad; ae; be; } \\
\text { ce) }\end{array}$ \\
\hline & 25 - 34 years & $29 \%$ & $2.1 \%$ & & $12 \%$ & $1.5 \%$ & \\
\hline & $35-44$ years & $24 \%$ & $2.3 \%$ & & $11 \%$ & $1.7 \%$ & \\
\hline & $45-59$ years & $20 \%$ & $2.2 \%$ & & $9 \%$ & $1.8 \%$ & \\
\hline & 60 years or above & $13 \%$ & $2.1 \%$ & & $4 \%$ & $1.1 \%$ & \\
\hline \multirow[t]{4}{*}{ Marital status } & Single & $32 \%$ & $2.6 \%$ & $<0.001(a b ; a c ; b c)$ & $17 \%$ & $2.5 \%$ & $<0.001(\mathrm{ab} ; \mathrm{ac})$ \\
\hline & Married/Concubine & $24 \%$ & $1.4 \%$ & & $10 \%$ & $1.0 \%$ & \\
\hline & Widower & $9 \%$ & $2.9 \%$ & & $4 \%$ & $1.7 \%$ & \\
\hline & Divorced/Separated & $22 \%$ & $3.9 \%$ & & $10 \%$ & $2.6 \%$ & \\
\hline \multirow[t]{4}{*}{ Schooling } & $\begin{array}{l}\text { Up to the } 5^{\text {th }} \text { grade, elementary } \\
\text { school }\end{array}$ & $19 \%$ & $1.7 \%$ & $<0.001(\mathrm{ab} ; \mathrm{ac})$ & $8 \%$ & $11 \%$ & $<0.001(a b)$ \\
\hline & $6^{\text {th }}-9^{\text {th }}$ grade, elementary school & $31 \%$ & $2.4 \%$ & & $17 \%$ & $2.1 \%$ & \\
\hline & High school & $28 \%$ & $2.1 \%$ & & $12 \%$ & $1.7 \%$ & \\
\hline & College & $22 \%$ & $4.1 \%$ & & $7 \%$ & $2.5 \%$ & \\
\hline \multirow{7}{*}{$\begin{array}{l}\text { Family } \\
\text { income }\end{array}$} & & & & 0.005 (bf; cf; df) & & & 0.041 \\
\hline & Up to $R \$ 450.00$ & $23 \%$ & $1.8 \%$ & & $11 \%$ & $1.3 \%$ & \\
\hline & $\mathrm{R} \$ 451.00$ to $\mathrm{R} \$ 750.00$ & $24 \%$ & $2.1 \%$ & & $12 \%$ & $2.2 \%$ & \\
\hline & $\mathrm{R} \$ 751.00$ to $\mathrm{R} \$ 1200.00$ & $27 \%$ & $2.6 \%$ & & $10 \%$ & $1.7 \%$ & \\
\hline & $\mathrm{R} \$ 1201.00$ to $\mathrm{R} \$ 2500.00$ & $31 \%$ & $3.6 \%$ & & $17 \%$ & $3.1 \%$ & \\
\hline & More than $\mathrm{R} \$ 2500.00$ & $29 \%$ & $5.5 \%$ & & $6 \%$ & $2.6 \%$ & \\
\hline & Does not know/refuses to answer & $12 \%$ & $2.8 \%$ & & $5 \%$ & $2.1 \%$ & \\
\hline \multirow[t]{5}{*}{ Region } & Northern & $25 \%$ & $3.6 \%$ & 0.764 & $17 \%$ & $4.6 \%$ & 0.521 \\
\hline & Center-Western & $30 \%$ & $5.2 \%$ & & $12 \%$ & $4.6 \%$ & \\
\hline & Northeastern & $26 \%$ & $2.7 \%$ & & $12 \%$ & $2.3 \%$ & \\
\hline & Southeastern & $24 \%$ & $1.6 \%$ & & $11 \%$ & $1.3 \%$ & \\
\hline & Southern & $24 \%$ & $3.2 \%$ & & $10 \%$ & $2.4 \%$ & \\
\hline \multirow[t]{2}{*}{ Area } & Countryside & $22 \%$ & $1.4 \%$ & 0.012 & $11 \%$ & $1.1 \%$ & 0.337 \\
\hline & Capital/Metropolitan region & $29 \%$ & $2.3 \%$ & & $13 \%$ & $2.0 \%$ & \\
\hline \multirow[t]{2}{*}{ Rural } & Urban & $26 \%$ & $1.3 \%$ & 0.043 & $12 \%$ & $1.1 \%$ & 0.343 \\
\hline & Rural & $19 \%$ & $2.7 \%$ & & $10 \%$ & $1.7 \%$ & \\
\hline Total & & $25 \%$ & $1.2 \%$ & & $11 \%$ & $1.0 \%$ & \\
\hline
\end{tabular}

* Test performed with logistic regression using a binary dependent variables. The characters between parentheses indicate pairs which art significantly different, according to multi-comparison tests with Bonferroni correction.

of the Northern and Northeastern regions, in the countryside and in rural sectors. Family income also seems to influence the consumption of liquors, which are more prevalent among individuals of lower income if compared to the consumption of other alcoholic beverages. However, this trend is reversed in the highest income range. Contrarily, spirits with mixers, still little known in Brazil, are present in a proportion above the average in the range of consumed beverages among young and single women with higher schooling levels and who live in metropolitan regions.

\section{Discussion}

This article presents the first nationwide overview of the consumption patterns of alcoholic beverages among the Brazilian adult population. The data show important differences in alcohol consumption, quantity, frequency, related problems and types of alcoholic beverages with regards to the diverse socio-demographic variables studied, suggesting that nationwide public policies should take these differences into account. The results show that so-called moderate drinking is not the rule among the Brazilian population. Generally, almost half of the population is abstinent, that is, they have not reported any alcohol consumption in the prior twelve months. On the other hand, among those who consume alcoholic beverages, almost one quarter has problems and consumes potentially harmful quantities. The implications of this dichotomous distribution of the population between abstainers and heavier drinkers are clear: given that much of the heavier 


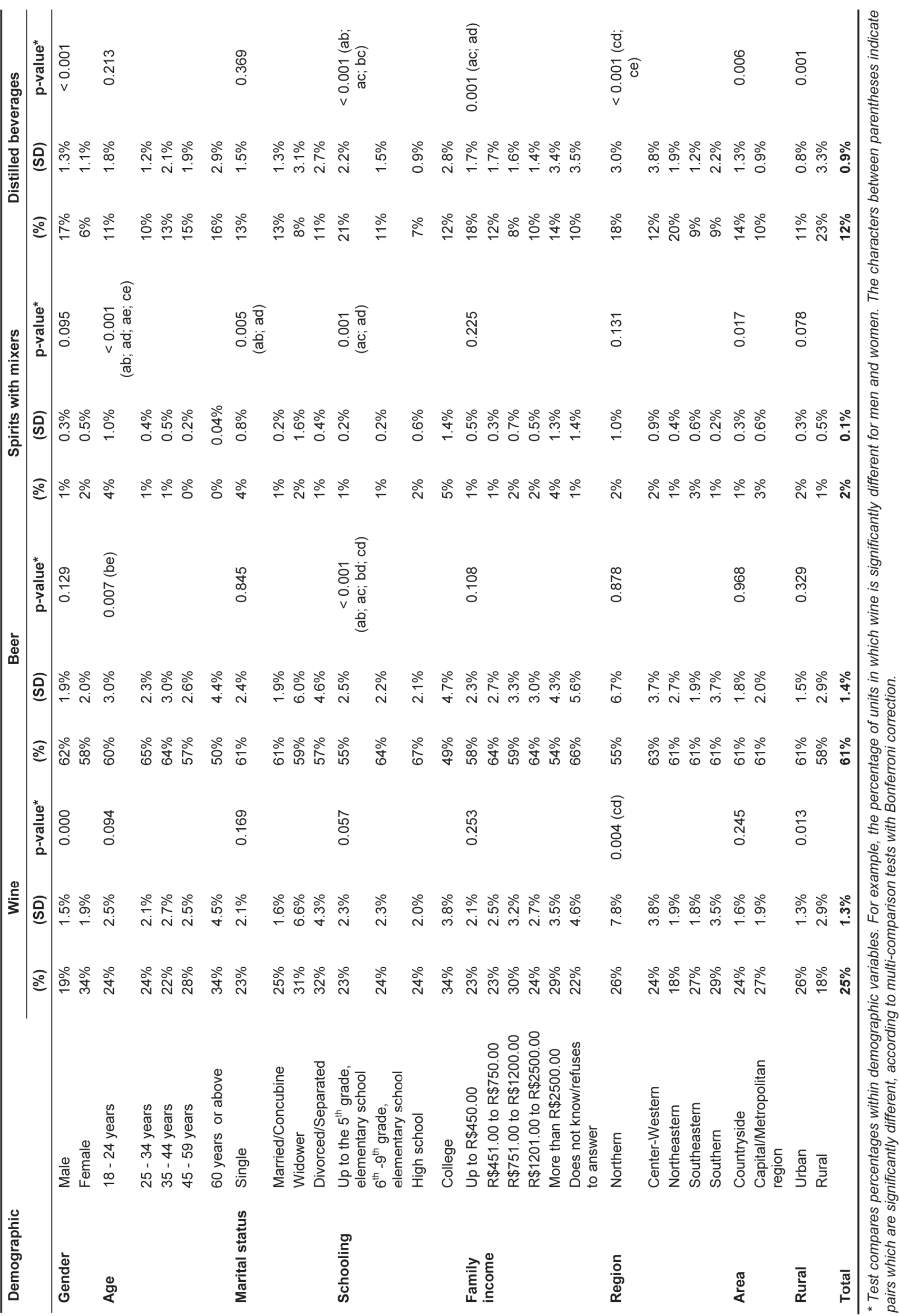


drinking is associated with binge drinking, i.e., the consumption of a large number of drinks in a single drinking occasion, it is important to try to minimize this specific type of drinking through prevention efforts. Further, the types of problems generated by this type of drinking are acute alcohol problems, such as falls, car crashes, and violence. Prevention interventions need therefore to focus on these problems, for instance promoting strict enforcement of drinking and driving laws to prevent drinking and driving.

Among men alcohol consumption is more frequently associated with those who are single and young, and the quantities consumed are higher and associated with more problems. It is noteworthy, however, that not only the very young ranges (18-25 years) present more problematic patterns. According to our sample, high consumption can continue up to the age of 44 years. In other countries, such as the US, high consumption falls rapidly after the twenties. High consumption among young American adults is considered to be related to these youngsters' lifestyle. ${ }^{18,19}$ Among Latinos in the US, the association of age with high consumption is more similar to our results. ${ }^{20,21}$ According to Caetano and Kaskutas, the explanation for the result shown among Latinos in the US is that men with more freedom to drink are the most mature and not the youngsters. This perhaps highlights the different place of drinking in Latin American and US cultures. ${ }^{22}$ Latin cultures did not have strong temperance movements, which in the US promoted a negative view of alcohol that is still somewhat culturally present today. Drinking in the US, and especially binge drinking, is seen therefore more negatively, as a behavior that only youth, but not mature men, indulges in. In Latin cultures, drinking is in general more integrated with daily activities and festivities. People of all ages participate in these activities, and drinking becomes not as strongly associated with age, especially among men, for whom drinking norms and attitudes are more lax and allow more drinking than for women.

Individuals with higher incomes have also shown significantly higher levels of alcohol consumption, and the consequent problems were registered. However, higher incomes were negatively associated with alcohol dependence, suggesting the role of social and economic factors in the prevalence of this diagnosis, such as the lower prevalence of alcohol dependence in the college level population, observed in our study. This has been a traditional finding in epidemiological studies in the general population. ${ }^{23,24}$ This finding is probably related to differences in patterns of drinking across income groups. It could also be that those with a lower income have fewer resources to respond personally to problems associated with heavier drinking.

There were regional differences in the consumption of alcoholic beverages in Brazil. The inhabitants of the Southern region drink more frequently, but in lower quantity. The opposite was seen in the Northeastern, Northern and Center-Western regions. Variations have also appeared regarding the type of beverages consumed, liquors being consumed more frequently in the Northeastern and Northern regions and wine in the Southern region. The similarities found are as interesting as the variations: the general rates of problems related to consumption, abuse and dependence did not vary per region, all being equally affected. In the same way, beer - by far the most preferred drink nationally - was consumed in similar quantities in all regions. One of the explanations for this regularity of beer consumption is the well organized national distribution of the product, its accessible prices and the promotional strategies which associates its consumption with every situation. ${ }^{25}$

Another reflection can be made about a type of risky consumption: binge drinking. For several years this consumption pattern has been internationally associated with a series of problems, including health impairments (wounds originated in accidents, hypertension, gastritis, pancreatitis), violence (homicides, fights, domestic and sexual violence), and occupational incidents (absence at school, at work). ${ }^{26,27}$ According to our data, more than one quarter of the population studied reported this type of alcohol consumption in the last twelve months, and this was more frequent among young and single men with higher purchasing power. Prevention programs should evaluate binge drinking as related to some of the main Brazilian issues, such as drinking and driving. A recent study points to binge drinking rates of nearly $20 \%$ in the sample studied, especially among the demographic group described above. ${ }^{3}$

The rates of harmful use and dependence are in accordance with those already reported by previous household studies. ${ }^{13,28}$ Taking into account that one third of men and a little more than half of women did not report consumption of any alcohol in the past year, the rates of abuse and dependence are considered high. For a comparison, these are the rates found in other countries: Israel ${ }^{29}$ $-4.3 \%$ of abuse or dependence; in the US ${ }^{30}-4.7 \%$ of abuse and $3.8 \%$ of dependence; in Chile ${ }^{31-} 6 \%$ of dependence; and in France ${ }^{32}$ $0.5 \%$ for abuse and $0.3 \%$ for dependence. The high abstention rate observed in the Brazilian population, in contrast with the high level of alcohol abuse and dependence, can be better understood by examining the drinker's alcohol consumption patterns. Our survey shows that there is a considerable proportion of drinkers - according to their own reports - who usually drink great amounts of alcohol and binge drink. That is, in Brazil many people do not drink, but those who drink tend to do it in a way that increases the risk of developing alcohol problems, abuse or dependence.

The findings of this study may help Brazilian authorities in the development of new public policies, aimed at reducing alcohol consumption's social burden. Our results clearly show - what was considered only as a supposition before that harmful alcohol consumption patterns are a significant problem in Brazil. The examination of their consequences should take into account not only the frequency of use but also the usual amount of consumption and binge drinking, as well as related problems and the types of beverages consumed. The regional differences regarding these variables and the detection of higher risk socio-demographic groups should be considered by authorities in order to establish more efficient nationwide policies. 


\section{Study limitations}

As mentioned earlier in this study, our survey does not include Native Brazilians who live in Indian reservations, and also populations who live in communities, such as prisons. This limitation is usual in population sample surveys and does not markedly affect the results of the present investigation. This is so because the excluded population represents a very small percentage of the national population. Another limitation is the fact that our results are based on the last national socio-demographic census, conducted in the year 2000. On the other hand, that gives us the opportunity to undertake a new survey soon, based on future 2010 IBGE census.

\section{Acknowledgements}

This project was made possible thanks to the sponsorship of the National Secretariat on Drugs Policies - SENAD - (process number 017/2003).

\section{Disclosures}

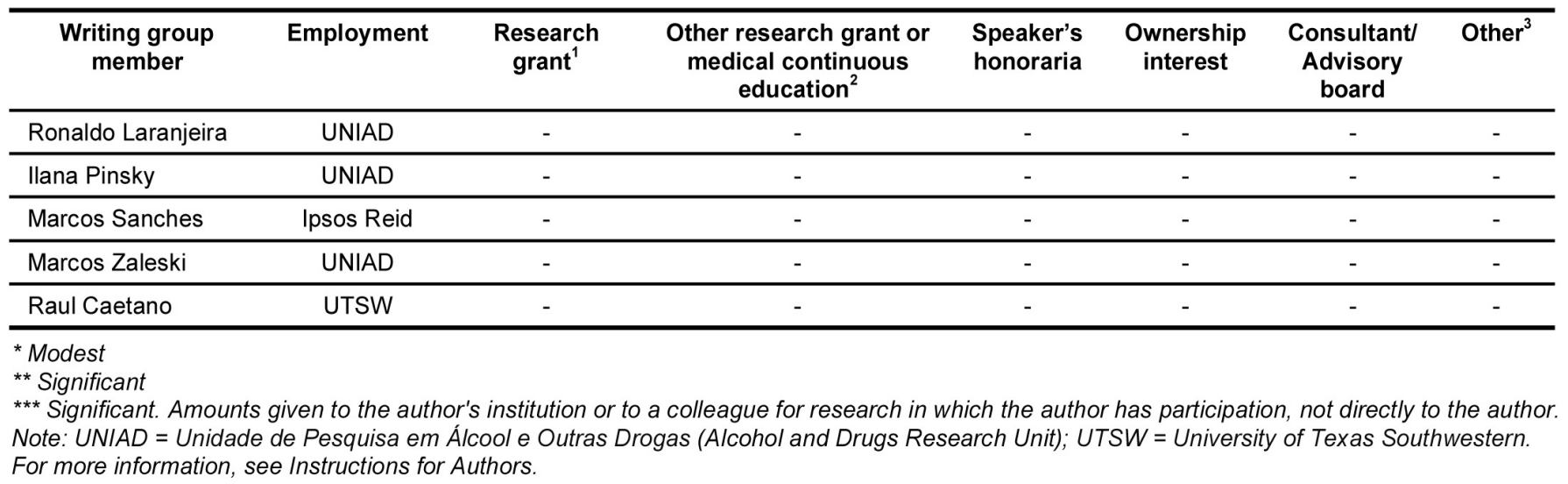

References

1. Courtney KE, Polich J. Binge drinking in young adults: data, definitions and determinants. Psychol Bull. 2009;135(1):142-56.

2. Barros MB, Botega NJ, Dalgalarrondo P, Marin-León L, de Oliveira HB Prevalence of alcohol abuse and associated factors in a population-based study. Rev Saude Publica. 2007;41(4):502-9.

3. Costa JS, Silveira MF, Gazalle FK, Oliveira SS, Hallal PC, Menezes AM, Gigante DP, Olinto MT, Macedo S. Heavy alcohol consumption and associated factors: a population-based study. Rev Saude Publica. 2004;38(2):284-91.

4. Mendoza-Sassi RA, Beria JU. Prevalence of alcohol use disorders and associated factors: a population based study using AUDIT in southern Brazil. Addiction. 2003;98(6):799-804.

5. Moreira LB, Fuchs FD, Moraes RS, Bredemeier M, Cardozo S, Fuchs SC, Victoria CG. Alcoholic beverage consumption and associated factors in Porto Alegre, a southern Brazilian city: a population-based survey. J Stud Alcohol. 1996;57(3):253-9.

6. Capriglione MJ, Monteiro MG, Masur J. Aplicação do questionário Cage para detecção da síndrome de dependência do álcool em 700 adultos na cidade de São Paulo. Rev Assoc Bras Psiquiatr. 1985;7(25):50-3.

7. Almeida-Filho N, Lessa I, Magalhães L, Araújo MJ, Aquino E, Kawachi I, James AS. Alcohol drinking patterns by gender, ethnicity, and social class in Bahia, Brazil. Rev Saude Publica. 2004;38(1):45-54.

8. Almeida-Filho N, Mari JJ, Coutinho E, França JF, Fernandes J, Andreoli SB, Busnello ED. Brazilian multicentric study of psychiatric morbidity. Methodological features and prevalence estimates. Br J Psychiatry. 1997;171:524-9.

9. Silveira CM, Wang YP, Andrade AG, Andrade LH. Heavy episodic drinking in the São Paulo epidemiologic catchment area study in Brazil: gender and sociodemographic correlates. J Stud Alcohol Drugs. 2007;68(1):18-27.

10. Galduróz JC, Noto AR, Nappo SA, Carlini EA. First household survey on drug abuse in São Paulo, Brazil, 1999: principal findings. São Paulo Med J. 2003a;121(6):231-7.

11. Galduróz JC, Noto AR, Nappo SA, Carlini EA. Comparaçōes dos resultados de dois levantamentos domiciliares sobre o uso de drogas psicotrópicas no estado de São Paulo nos anos de 1999 a 2001. J Bras Psiq. 2003b;52(1):43-51.

12. Kerr-Corrêa F, Tucci AM, Hegedeus AM, Trinca LA, de Oliveira JB, Floripes TM, Kerr LR. Drinking patterns between men and women in two distinct Brazilian communities. Rev Bras Psiquiatr. 2008;30(3):235-42.
13. Carlini EA, Galduróz JC, Noto AR, Fonseca AM, Carlini CM, Oliveira LG, Nappo AS, Moura YG, Sanchez ZM. II Levantamento domiciliar sobre o uso de drogas psicotrópicas no Brasil - 2005. Cebrid - Centro Brasileiro de Informações sobre Drogas Psicotrópicas - Departamento de Psicobiologia da Escola Paulista de Medicina e SENAD - Secretaria Nacional Antidrogas, Presidência da República, Gabinete de Segurança Nacional; 2007. p.468.

14. Galduróz JC, Carlini EA. Use of alcohol among the inhabitants of the 107 largest cities in Brazil - 2001. Braz J Med Biol Res. 2007;40(3):367-75.

15. Instituto Brasileiro de Geografia e Estatística - IBGE. Censo demográfico 2000. Rio de Janeiro; 2002.

16. Caetano R, Ramisetty-Mikler S, Rodriguez LA. The Hispanic Americans Baseline Alcohol Survey (HABLAS): the association between birthplace, acculturation and alcohol abuse and dependence across Hispanic national groups. Drug Alcohol Depend. 2009;99(1-3):215-21.

17. Cottler LB, Robins LN, Helzer JE. The reliability of the CIDI-SAM: a comprehensive substance abuse interview. Br J Addict. 1989;84(7):801-14.

18. Cahalan D, Room R. Problem drinking among American men. Rutgers Center of Alcohol Studies [monograph 7],1974.

19. Laska MN, Pasch KE, Lust K, Story M, Ehlinger E. Latent class analysis of lifestyle characteristics and health risk among College Youth. Prev Sci. In press 2009.

20. Caetano R. Findings from the 1984 national survey of alcohol use among U.S Hispanics. In: Clark WB, Hilton ME. Alcohol in America: drinking practices and problems. Albany: State University of New York Press; 1991. p.293-308.

21. Ramisetty-Mikler S, Caetano R, Rodriguez LA. The Hispanic Americans Baseline Alcohol Survey (HABLAS): alcohol consumption and sociodemographic predictors among Hispanic national groups in the United States. University of Texas School of Public Health; 2008.

22. Caetano R, Kaskutas L. Changes in drinking patterns among whites, blacks and Hispanics: 1984-1992. J Stud Alcohol. 1995;56(5):558-65.

23. Grant BF, Dawson DA. Age at onset of alcohol use and its association with DSM-IV alcohol abuse and dependence: results from the National Longitudinal Alcohol Epidemiologic Survey. J Subst Abuse. 1997;9: 103-10.

24. Grant BF, Harford TC, Dawson DA, Chou P, Dufour M, Pickering R. Prevalence of DSM-IV alcohol abuse and dependence. Alcohol Health Res World. 1994:18:243-8. 
25. Jette S, Sparks R, Pinsky I, Castaneda L, Haines R. Youth, sports and the culture of beer drinking: global alcohol sponsorship of sports and cultural events in Latin America. In: Jackson S, Wenner L, editors. Sport, beer, and gender in promotional culture: explorations of a Holy Trinity. Peter Lang Publishing Group; 2008.

26. McMahon J, McAlaney J, Edgar F. Binge drinking behavior, attitudes and beliefs in a UK community sample: an analysis by gender, age and deprivation. Drugs education, prevention and policy (Abingdon, England). 2007;14(4):289-303.

27. Naimi TS, Brewer RD, Mokdad A, Denny C, Serdula MK, Marks J. Binge drinking among US adults. JAMA. 2003;289(1):70-5.

28. Galduróz JC, Carlini EA. Use of alcohol among the inhabitants of the 107 largest cities in Brazil - 2001. Braz J Med Biol Res. 2007;40(3):367-75.

29. Neumark YD, Lopez-Quintero C, Grinshpoon A, Levinson D. Alcohol drinking patterns and prevalence of alcohol-abuse and dependence in the Israel National Health Survey. Isr J Psychiatry Relat Sci. 2007;44(2): 126-35.

30. Grant BF, Dawson DA, Stinson FS, Chou SP, Dufour MC, Pickering RP. The 12-month prevalence and trends in DSM-IV alcohol abuse and dependence: United States, 1991-1992 and 2001-2002. Drug Alcohol Depend. 2004;74(3):223-34.

31. Vicente B, Rioseco P, Saldivia S, Kohn R, Torres S. Chilean study on the prevalence of psychiatric disorders (DSM-III-R/CIDI). Rev Med Chil. 2002;130(5):527-36.

32. Lépine JP, Gasquet I, Kovess V, Arbabzdeh-Bouchez S, Nègre-Pagès L, Nachbaur G, Gaudin AF. Prevalence and comorbidity of psychiatric disorders in the French general population. Encephale. 2005;31(2):182-94. 